\title{
Prediction of Human Error Probability for Possible Gas Turbine Faults in Marine Engineering
}

\author{
Hakan DEMİREL
}

Zonguldak Bülent Ecevit University, Maritime Faculty, Turkey

hakandemirel@beun.edu.tr; ORCID ID: https://orcid.org/0000-0002-7579-7064

\begin{abstract}
For all areas where operational activities exist, human error possibilities are of critical importance. In this sense, maintenance, management and monitoring of all components in ships powered by gas turbine systems is a condition that must be observed. At this point, the importance of human impact is great and plays a critical role. In this study, the probabilities of human error on the 14 critical faults described in the literature for gas turbine components are calculated by the CREAM method in the sense of expert opinions. The results clearly indicate the importance of human impact on faults, and guide the technical personnel to be employed on board ship during the operation. This study provides the basis for further studies in this area.
\end{abstract}

Keywords: Marine Engineering, Gas Turbine, Human Error Prediction, CREAM.

\section{Deniz Mühendisliğinde Olası Gaz Türbini Arızaları için İnsan Hatası Olasılığının Tahmini}

Öz

Operasyonel faaliyetlerin olduğu tüm alanlar için insan hatası olasıllkları kritik öneme sahiptir. Bu anlamda gaz türbin sistemleri ile seyir eden gemilerdeki bütün bileșenlerin bakımı, yönetimi ve izlenmesi gerekli bir durumdur. Bu noktada insan etkisinin önemi büyük ve kritik bir rol oynamaktadır. Bu çalışmada, gaz türbini bileșenleri için literatürde ifade edilen 14 kritik arızadaki insan hatası olasılığı, uzman görüşleri alınarak, CREAM yöntemi ile hesaplanmıştır. Elde edilen sonuçlar, arızalar üzerinde insan etkisinin ne kadar önemli olduğunu net bir șekilde ifade etmektedir ve operasyon boyunca gemide çalıştırllacak teknik personele dikkat etmesi gereken durumlar açısından yol gösterici niteliktedir. Bu çalışma bu alanda yapılacak daha sonraki çalışmalar için temel oluşturmaktadır.

Anahtar Kelimeler: Deniz Mühendisliği, Gaz Türbini, İnsan Hatası Tahmini, CREAM. 


\section{Introduction}

Human error analysis studies are increasing rapidly and many field applications are being made [1]. The problems that arise in industrial facilities due to human-induced faults make this situation even more complicated [2]. Human factor plays an important role in industrial reliability and safety analysis. At this point, any accidental loss that may occur in real life must be considered.

When a component of an industrial plant or system is examined and risk assessed, a structure that identifies all the points of the system arises. This relationship is clarified by determining the boundaries of the accepted system and revealing its functional properties. The operation and maintenance of the system is an important part of this analysis.

Gas turbine systems are preferred internal combustion engines in marine vehicles and power plants [3]. These systems require manufacturing precision and qualified workforce. There is a need to build a specific point of view for gas turbines. Thus, new situations that may occur in malfunctioning or undamaged engines are taken into consideration. In most cases, it is known that faults cause serious damage and a significant loss of capital investment. In this case, it is very clear that the gas turbine components must be handled carefully. The types and severity of faults in gas turbine components are different from those due to operating conditions.

Maintenance personnel has a critical role in the safe operation of gas turbine components. It is known that most human errors occur in the course of the maintenance of equipment. For this reason, it is significant that focusing on the human errors during the maintenance phase. By analyzing the errors that people make on the system, the new system structures can be developed to reduce both error occurrence and effects.

The aim of this study is to determine the probabilities of human error on possible faults in gas turbine systems. It is emphasized by the opinions of experts in the field and the Cream method that the determined probabilities are important for the technical personnel involved in the gas turbine operations.

\section{Literature Review}

Gas turbine technology involves complex technical systems that are managed by human influence. This clearly indicates the impact of people on the safe operation of the system. Recently, analysis of large accidents has revealed that human error plays an important role. However, there are some fundamental problems in the analysis of accidents and in the definition of human error. The human adaptability and learning ability are the subjects that should be examined in particular when it comes to analyzing the concept of human error. All these expressions show that errors cannot be considered separately from the system in modern working environments. This is an undeniable effect on the faults in gas turbine systems.

Doel. (1990) investigated the condition monitoring of gas turbine engines and developed software algorithms for the interpretation of the limited available sensors [4]. Bea (1994) summarized the impacts of human errors in marine and non-marine structures[5]. Dearden and Harrison (1996, June) examined the relationship between operator actions and system hazards and presented a simple case study about the human-machine interface (HMI) [6]. DePold and Gass (1998, June) presented maintenance strategies for gas turbine engine generators and used artificial neural network filters to improve data quality[7]. Brotherton et al. (2000) evaluated the critical component faults in gas turbine engines and developed 
a new technique by the help of data collected from operating engines[8]. Latorella and Prabhu (2000) mentioned the productivity and efficiency of airline operations and evaluated the human error in aviation maintenance and inspection [9]. Rothblum(2000) studied the causes of human error in the maritime industry [10]. Ganguli (2002) developed a Fuzzy logic intelligent system for gas turbine fault isolation [11]. Li (2002) proposed the performance analysis based method for gas turbine fault diagnosis [12]. Mosleh and Chang (2004) evaluated operator response in probabilistic safety assessments (PSA) of nuclear power plants and proposed the conventional method for human reliability analysis (HRA) [13]. Konstandinidou et al. (2006) used a fuzzy classification system for human reliability analysis and proposed cognitive reliability and error analysis method (CREAM) for maintenance tasks in control room operations [14]. Dhillon and Liu (2006) analyzed and reviewed the human error in maintenance systematically [15].Kim et al. (2011) examined the human error probabilities related marine accidents using an analysis method [16]. Yang et al. (2013) determined the human reliability performance using a modified CREAM[17]. Noroozi et al. (2014) analysed the human factors in pre- and post-maintenance operations. They used a pump as the test example and calculated the human error probability (HEP) [18]. Islam et al. (2016) calculated the human error probabilities for 43 different activities of marine engines [19]. Islam et al. (2018) evaluated the maintenance operations on board ships and developed human error probability model for seafarers[1].

In the view of mentioned studies, although there has been a wide variety of evaluations to assess human error, human error probabilities on faults in gas turbine systems using the Cream method have not been evaluated. In order to correct this gap, this article aims to determine the possibility of human error in certain faults in gas turbine operations in the maritime industry.

\section{CREAM Methodology}

A robust methodology allowing the prediction of human error probability and the analysis of cognitive human reliability, Hollnagel (1998) introduced CREAM method, which is suited to perform retrospective and prospective examination [20]. This method identifies parts of the work, tasks or actions requiring or dependent upon human recognition and therefore, open to the effect of variations in cognitive reliability. Some researchers (e.g. Akyuz, 2015) attempted to draw fine distinctions between basic and extended versions of the CREAM in which a comprehensive human error assessment is made [21]. The basic one focuses on initial screening of human interactions, the extended one a far-reaching analysis for human interaction by adopting outputs of the basic version.

For the determination of the probability of human error in numerous actions, the CREAM is comprised of four different control modes. It is a derivation of COCOM (Contextual Control Model) addressing the practical and conceptual basis for the improvement of human performance[21-22]. The models are scrambled, opportunistic, tactical and strategic. Due to the strategic mode introducing the lowest probability of human error, the highest human error probability is alluded by the scrambled control mode. Table 1 below illustrates control modes and relevant failure probabilities. With the aim of quantifying the probability of human error, the CREAM embraces a few main steps. 
Table 1. Control Modes and HEP Intervals

\begin{tabular}{|l|l|}
\hline \multicolumn{1}{|c|}{ Control Mode } & \multicolumn{1}{c|}{ HEP Interval } \\
\hline Strategic & $0.5 \mathrm{E}-5<\mathrm{P}<1.0 \mathrm{E}-2$ \\
\hline Tactical & $1.0 \mathrm{E}-3<\mathrm{P}<1.0 \mathrm{E}-1$ \\
\hline Opportunistic & $1.0 \mathrm{E}-2<\mathrm{P}<0.5 \mathrm{E}-0$ \\
\hline Scrambled & $1.0 \mathrm{E}-1<\mathrm{P}<1.0 \mathrm{E}-0$ \\
\hline
\end{tabular}

\subsection{Introducing Control Modes}

Based on COCOM, the theoretical background of CREAM with four control modes, as explained above, is scrambled, opportunistic, tactical and strategic. Experiences of personnel and knowledge of dependency are influential in the control modes. Control modes and effects are shortly given: [23].

Scrambled control mode: The operator's exerting minimum control over the system is indicated by scrambled modes because of the randomness or unpredictability of the choice of next action.

Opportunistic control mode: Careless characteristics of the situation stemming from lack of time, inexperienced operator, etc. determine the choice of next action.

Tactical control mode: Performance of operator nearly follows planned procedures; albeit, still the possibility of some deviation.

Strategic control mode: In addition to the time available, operator conceivably

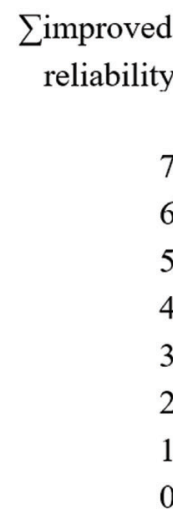

thinks action at a higher level. This mode enables more efficient action than the others to be conducted by the operator.

For initial screening of human failure events to be monitored, Figure 1 is usable and defines the basic operator control modes[23].

\subsection{Assess Common Performance Conditions (CPCs)}

Definition and assessment of CPC are required in this method to find out cognition and human context. The CPC state the conditions of the operator such as a performance shaping factors which are excessively influential on the human error. CPCs level and relevant performance effect are illustrated in Table 2 [20].

So as to predict the probability of human error, the CPC score is required. In the calculation of the CPC score, the number of times, which gives rise to decrease performance reliability or increase performance reliability, is considered. Subsequent to the accumulation of CPC scores, the control modes are established to determine human error probability interval. The combined CPC scores, $\sum$ reduced and $\sum$ improved signify the appropriate control mode providing the probability of human failure intervals. Conversely, CPC $\sum$ not significant does not affect the HEP [21].

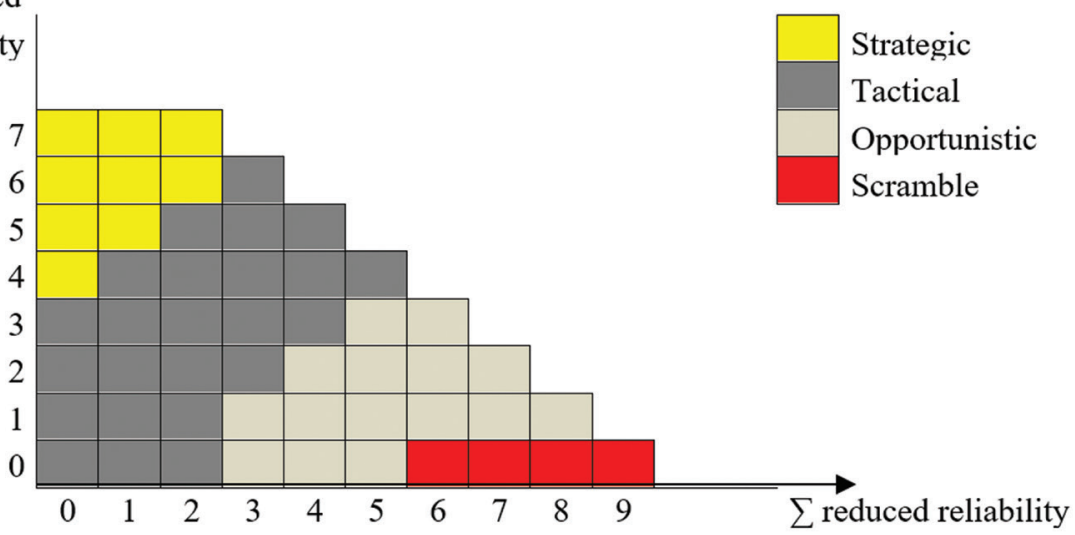

Figure 1. Operator Control Modes 
Table 2. CPC Level and Performance Effect

\begin{tabular}{|c|c|c|}
\hline $\mathrm{CPC}$ & CPC level/description & Effects \\
\hline \multirow[t]{4}{*}{ Adequacy of organisation } & Very efficient & Improved \\
\hline & Efficient & Not significant \\
\hline & Inefficient & Reduced \\
\hline & Deficient & Reduced \\
\hline \multirow[t]{3}{*}{ Working conditions } & Advantageous & Improved \\
\hline & Compatible & Not significant \\
\hline & Incompatible & Reduced \\
\hline \multirow{4}{*}{$\begin{array}{l}\text { Adequacy of MMI and } \\
\text { operational support }\end{array}$} & Supportive & Improved \\
\hline & Adequate & Not significant \\
\hline & Tolerable & Not significant \\
\hline & Inappropriate & Reduced \\
\hline \multirow[t]{3}{*}{ Availability of procedures/plans } & Appropriate & Improved \\
\hline & Acceptable & Not significant \\
\hline & Inappropriate & Reduced \\
\hline \multirow{3}{*}{$\begin{array}{l}\text { Number of simultaneous } \\
\text { goals }\end{array}$} & Fewer than capacity & Not significant \\
\hline & Matching current capacity & Not significant \\
\hline & More than capacity & Reduced \\
\hline \multirow[t]{3}{*}{ Available time } & Adequate & Improved \\
\hline & Temporarily inadequate & Not significant \\
\hline & Continuously inadequate & Reduced \\
\hline \multirow[t]{2}{*}{ Time of day } & Day-time (adjusted) & Not significant \\
\hline & Night-time (unadjusted) & Reduced \\
\hline \multirow{3}{*}{$\begin{array}{l}\text { Adequacy of training and } \\
\text { experience }\end{array}$} & Adequate, high experience & Improved \\
\hline & Adequate, limited experience & Not significant \\
\hline & Inadequate & Reduced \\
\hline \multirow[t]{4}{*}{ Crew collaboration quality } & Very efficient & Improved \\
\hline & Efficient & Not significant \\
\hline & Inefficient & Not significant \\
\hline & Deficient & Reduced \\
\hline
\end{tabular}

\subsection{Identifying context influence index (CII)}

By dint of CII in the CREAM, quantification of human error is ensured. Herein, the CPCs are likely to be quantified. The deduction of the number of reduced CPCs from improved CPCs ascertains this value. An equation (1) demonstrates the quantification process of CII. In the equation, $\mathrm{X}$ provides the number of reduced CPCs and Y indicates the number of improved CPCs [21-24].

CII $=X-Y=\sum$ reduced $-\sum$ improved

He et al. (2008) describe a specific control mode capable of converting CII into a crisp value in line with the CPCs score [24]. Table 3 displays specific control modes and CII values in which the control modes are 
classified [23-24]. In the control modes, as $\sum$ not significant combined CPCs scores have no significant effect over the HEP value, the CII value is considered 0 .

Table 3. Specific Control Modes and CII Values

\begin{tabular}{|l|l|}
\hline \multicolumn{1}{|c|}{ Control mode } & \multicolumn{1}{c|}{ CII values } \\
\hline Strategic & -7 to -3 \\
\hline Tactical & -3 to 1 \\
\hline Opportunistic & 2 to 5 \\
\hline Scrambled & 6 to 9 \\
\hline
\end{tabular}

\subsection{Predicting Performance Influence Index (PII)}

Akyuz (2015) argues the PII values were introduced with the aim of specifying the actual weighting factors for cognitive functions such as planning, executing, observation and interpretation [21]. Each CPC possesses a different PII value and each one of them is a different weighting factor from others. This calculation serves to monitor screening stage. Equation (2), within this scope, shows CII value in relation to PII. In the equation, the PII value basis of the weighting factor is introduced in CREAM extended version and arranged by expert judgement [21-24].

$$
C I I=\sum_{i=1}^{9} P I I
$$

\subsection{Calculating Cognitive Failure Probability (CFP)}

In this step, cognitive human failure probability is decided, for human failure probability for each cognitive failure type is defined by CFP. The nominal cognitive failure probability (CFP0) is designated for each operational task. The CFP0 acquires a set of sources and provides the nominal value given for failures of cognitive function [20-21]. In CREAM, under four cognitive functions are introduced thirteen generic failure types. Table 4 [23-24] illustrates nominal cognitive failure probability.

According to Akyuz (2015), He et al. (2008), Apostolakis et al. (1988) the following equation (3) identifies the correlation between the CII and CFP [21-24-25]. The logarithmic equation is employed to depict changes in human error interactions with the variance in external conditions.

$$
\log \left(\frac{C F P}{C F P_{0}}\right)=k . C I I
$$

In the equation, $\mathrm{k}$ explains a constant

Table 4. Nominal Cognitive Failure Probability

\begin{tabular}{|l|l|c|}
\hline \multicolumn{1}{|c|}{ Cognitive Function } & \multicolumn{1}{|c|}{ Generic Failure Type } & \multicolumn{1}{c|}{ Basic Value } \\
\hline \multirow{5}{*}{ Observation } & 01. Wrong object observed & $1.0 \mathrm{E}-3$ \\
\cline { 2 - 3 } & O2. Wrong identification & $7.0 \mathrm{E}-2$ \\
\cline { 2 - 3 } & O3. Observation not made & $7.0 \mathrm{E}-2$ \\
\hline \multirow{5}{*}{ Interpretation } & I1. Failurey diagnosis & $2.0 \mathrm{E}-1$ \\
\cline { 2 - 3 } & I2. Decision error & $1.0 \mathrm{E}-2$ \\
\cline { 2 - 3 } & I3. Delayed interpretation & $1.0 \mathrm{E}-2$ \\
\hline \multirow{5}{*}{ Planning } & P1.Priority error & $1.0 \mathrm{E}-2$ \\
\cline { 2 - 3 } & P2.Inadequate plan & $1.0 \mathrm{E}-2$ \\
\hline \multirow{5}{*}{ Execution } & E1. Action of wrong type & $3.0 \mathrm{E}-3$ \\
\cline { 2 - 3 } & E2. Action at wrong time & $3.0 \mathrm{E}-3$ \\
\cline { 2 - 3 } & E3. Action on wrong object & $5.0 \mathrm{E}-4$ \\
\cline { 2 - 3 } & E4. Action out of sequence & $3.0 \mathrm{E}-3$ \\
\cline { 2 - 3 } & E5. Missed action & $3.0 \mathrm{E}-2$ \\
\hline
\end{tabular}


coefficient and determined by following equations (4), (5), (6) and (7) [24].

$$
\begin{aligned}
& \log \left(\mathrm{CFP}_{\max } / \mathrm{CFP}_{0}\right)=k \cdot \mathrm{CII}_{\text {max }}, \\
& \log \left(\mathrm{CFP}_{\min } / \mathrm{CFP}_{0}\right)=k \cdot C I I_{\text {min }} \\
& k=\log \left(\mathrm{CFP}_{\max } / \mathrm{CFP}_{\min }\right) /\left(\mathrm{CII}_{\max }-\mathrm{CII}_{\min }\right) \\
& \mathrm{CFP}_{0}=\mathrm{CFP}_{\text {max }} / 10^{\mathrm{k} \cdot \mathrm{CII} \text { max }}
\end{aligned}
$$

Akyuz (2015) points out, $\mathrm{k}$ is found 0.26 by considering CFPmax as 1.0000 and CFPmin as 0.00005 [21]. In the light of findings, equation (8) is utilized to calculate adjusted CFP which also specifies HEP.

$$
C F P=C F P_{0} \times 10^{0.26 . C I I}
$$

\section{Application}

\subsection{Operation of Gas Turbine Components in Ship}

Gas turbines have been used to propel ships for many years, all nations have evaluated this technology in war ships and commercial fleets. A gas turbine engine is referred to as an internal combustion engine that utilizes gas as a working fluid to rotate the turbine. This engine comprises a compressor, a combustor, a turbine, output shaft \& gearbox, and an exhaust. In gas turbine technology, the air-fuel mixture is ignited after hot gas turns turbine blades so that the turbine drive shaft rotates. Generator power is provided with the return of the turbine. As a result, the generator magnet moves electrons and electricity is generated at this point [8-11].

Gas turbines are complex systems and many faults can occur in different parts of them. Hydraulic-Pneumatic Equipment, Electronic Control Equipment and Bearing Equipment are important parts of gas turbines. There are many points to be checked by the seafarers regarding this equipment. Especially, fuel and pressure regulator filter, oiling pressure, valve pressure and temperature value for related equipment must be checked by seafarers considering the values determined by the manufacturers for the equipment.

The maintenance person plays an important role in equipment reliability and management. It is known that human error often occurs during the maintenance phase. So critical values of the relevant equipment must be checked in time so that no failure occurs in the gas turbine components.

\subsection{Problem Description}

In the management of gas turbine technology, it is known that serious damage caused by human error occurs and capital investment is lost in a significant amount. Many faults occur on the gas turbine components due to human influence. The faults in the gas turbine components are described as in Table 5 [26-27].

These faults and possible effects in the gas turbine components are shown as in Table 5. When the causes of these faults are examined, the importance of human effect is great. Because all the components are operated with the values given by the manufacturer and these controls are made with human influence.

\subsection{Analysis of Respondents}

It is important to get the views of experts in the field of inadequate information access in the maritime industry. Three expert opinions were received in this study. One of them is a professor in the department of marine engineering operations and has been working as a teaching member for more than 10 years. The other one is the third engineer on the ships and also the manager of a maritime company and has 6 years working experience. Lastly, he is as a naval architecture and 
Table 5. Possible Operational Gas Turbine Faults

\begin{tabular}{|c|c|c|}
\hline No & & Potential faults \\
\hline \multirow[t]{4}{*}{1.} & \multicolumn{2}{|c|}{ Variations in rpm signal } \\
\hline & F1. & Electronic speed regulator failure \\
\hline & F2. & Starter motor coupling failure \\
\hline & F3. & Connecting shaft has been broken between turbine and gear box \\
\hline \multirow[t]{4}{*}{2.} & \multicolumn{2}{|c|}{ Falling and fluctuations in pressure value } \\
\hline & F4. & Sufficient pressure fuel does not come for fuel pump \\
\hline & F5. & The oil pressure switch failure \\
\hline & F6. & The fuel solenoid valve failure \\
\hline \multirow[t]{4}{*}{3.} & \multicolumn{2}{|c|}{ Insufficient compressed air flow } \\
\hline & F7. & Blocked the outlet of air pressure regulator \\
\hline & F8. & Load control valve failure \\
\hline & F9. & Pressure regulator filter clogged \\
\hline \multirow[t]{4}{*}{4.} & \multicolumn{2}{|c|}{ Excessive change in exhaust gas temperature } \\
\hline & F10. & Temperature control unit failure \\
\hline & F11. & Problems in automatic control air supply lines \\
\hline & F12. & Fuel atomiser filter clogged \\
\hline \multirow[t]{3}{*}{5.} & \multicolumn{2}{|c|}{ Turbine Vibrations } \\
\hline & F13. & Eccentricity of shafts \\
\hline & F14. & Low oiling pressure \\
\hline
\end{tabular}

marine engineer and has worked as a maintenance engineer for shipyards for 6 years. The causes and defects of gas turbine faults were evaluated by these 3 experts. The answers given by the experts were evaluated using the CREAM method and realistic results were obtained.

\subsection{Extensive Human Error Prediction for Operation Procedure of Gas Turbine Components}

Table 5 provides the significant gas turbine faults (F) stemmed from human error during operation. The potential operational faults arising from human errors are evaluated through brainstorming of three experts.

Prior to determining the CPC, working environment of the gas turbine, time of day, engine crew collaboration, noise level, engine crew ability, and fatigue level are assessed by the marine experts. Table 6 presents the descriptor of the CPCs evaluation by the consensus of marine experts.

Thus, the CPC effects through engine crew performance reliability are available related to Table 2 . In this regard, the equation (1) is utilized to quantify. The CII value, here, can be found as CII $=-1$ for No.1 (high heat level in all exhaust cylinders of the engine) No.1, CII $=-2$ for No.2, CII $=0$ for No.3, CII $=2$ for no.4, CII=2 for No.5 and CII= -2 for No.6 in diesel engine operational faults owing to human error. In consideration of the findings, the PII values of the CPCs are described in Table 7. The quantification process of CII value in the extended version of CREAM is presented applying equation (2) and same provided in Table 8 as well [20]. 
Table 6. CPCs Evaluation by the Consensus of Experts

\begin{tabular}{|c|c|c|c|c|c|}
\hline \multicolumn{6}{|c|}{ CPCs and performance reliability } \\
\hline CPC & $\begin{array}{l}\text { Falling and } \\
\text { Fluctuations in } \\
\text { Pressure Value }\end{array}$ & $\begin{array}{l}\text { Variations in } \\
\text { rpm signal }\end{array}$ & $\begin{array}{c}\text { Insufficient } \\
\text { compressed air } \\
\text { flow }\end{array}$ & $\begin{array}{c}\text { Excessive } \\
\text { change in } \\
\text { exhaust gas } \\
\text { temperature }\end{array}$ & $\begin{array}{c}\text { Turbine } \\
\text { Vibrations }\end{array}$ \\
\hline $\begin{array}{l}\text { Adequacy of } \\
\text { organisation }\end{array}$ & Very Efficient & Efficient & Very Efficient & Efficient & Efficient \\
\hline $\begin{array}{l}\text { Working } \\
\text { conditions }\end{array}$ & Compatible & Advantageous & Advantageous & Compatible & Incompatible \\
\hline $\begin{array}{l}\text { Adequacy } \\
\text { of MMI and } \\
\text { operational } \\
\text { support }\end{array}$ & Tolerable & Supportive & Tolerable & Supportive & Supportive \\
\hline $\begin{array}{l}\text { Availability of } \\
\text { procedures/ } \\
\text { plans }\end{array}$ & Appropriate & Acceptable & Acceptable & Inappropriate & Acceptable \\
\hline $\begin{array}{l}\text { Number of } \\
\text { simultaneous } \\
\text { goals }\end{array}$ & $\begin{array}{c}\text { Matching } \\
\text { current capacity }\end{array}$ & $\begin{array}{l}\text { More than } \\
\text { capacity }\end{array}$ & $\begin{array}{c}\text { Matching } \\
\text { current capacity }\end{array}$ & $\begin{array}{c}\text { Fewer than } \\
\text { capacity }\end{array}$ & $\begin{array}{l}\text { More than } \\
\text { capacity }\end{array}$ \\
\hline Available time & $\begin{array}{l}\text { Temporarily } \\
\text { inadequate }\end{array}$ & Adequate & $\begin{array}{l}\text { Temporarily } \\
\text { inadequate }\end{array}$ & $\begin{array}{l}\text { Temporary } \\
\text { inadequate }\end{array}$ & Adequate \\
\hline Time of day & Day-time & Day-time & Night-time & Night-time & Day-time \\
\hline $\begin{array}{l}\text { Adequacy of } \\
\text { training and } \\
\text { experience }\end{array}$ & $\begin{array}{c}\text { Adequate } \\
\text { limited } \\
\text { experience }\end{array}$ & $\begin{array}{l}\text { Adequate high } \\
\text { experience }\end{array}$ & $\begin{array}{c}\text { Adequate } \\
\text { limited } \\
\text { experience }\end{array}$ & $\begin{array}{l}\text { Adequate high } \\
\text { experince }\end{array}$ & $\begin{array}{l}\text { Adequate high } \\
\text { experience }\end{array}$ \\
\hline $\begin{array}{l}\text { Crew } \\
\text { collaboration } \\
\text { quality }\end{array}$ & Efficient & Very Efficient & Efficient & Deficient & Very Efficient \\
\hline
\end{tabular}

Table 7. PII for CPCs (cont')

\begin{tabular}{|l|l|c|}
\hline \multicolumn{1}{|c|}{ CPC } & \multicolumn{1}{|c|}{ CPC Level } & PII \\
\hline \multirow{4}{*}{ Adequacy of organisation } & Very efficient & -0.6 \\
\cline { 2 - 3 } & Efficient & 0 \\
\cline { 2 - 3 } & Inefficient & 0.6 \\
\cline { 2 - 3 } & Deficient & 1.0 \\
\hline \multirow{4}{*}{ Working conditions } & Advantageous & -0.6 \\
\cline { 2 - 3 } & Compatible & 0 \\
\cline { 2 - 3 } & Incompatible & 1.0 \\
\hline \multirow{4}{*}{$\begin{array}{l}\text { Adequacy of MMI and } \\
\text { operational support }\end{array}$} & Supportive & -1.2 \\
\cline { 2 - 3 } & Adequate & -0.4 \\
\cline { 2 - 3 } & Tolerable & 0 \\
\cline { 2 - 3 } & Inappropriate & 1.4 \\
\hline \multirow{3}{*}{$\begin{array}{l}\text { Availability of procedures/ } \\
\text { plans }\end{array}$} & Appropriate & -1.2 \\
\cline { 2 - 3 } & Acceptable & 0 \\
\cline { 2 - 3 } & Inappropriate & 1.4 \\
\hline \hline
\end{tabular}


Table 7. PII for CPCs (cont')

\begin{tabular}{|l|l|c|}
\hline \multicolumn{1}{|c|}{ CPC } & \multicolumn{1}{|c|}{ CPC Level } & PII \\
\hline \multirow{4}{*}{$\begin{array}{l}\text { Number of simultaneous } \\
\text { goals }\end{array}$} & Fewer than capacity & 0 \\
\cline { 2 - 3 } & Matching current capacity & 0 \\
\cline { 2 - 3 } & More than capacity & 1.2 \\
\hline \multirow{4}{*}{ Available time } & Adequate & -1.4 \\
\cline { 2 - 3 } & Temporarily inadequate & 1.0 \\
\cline { 2 - 3 } & Continuously inadequate & 2.4 \\
\hline \multirow{3}{*}{ Time of day } & Day-time (adjusted) & 0 \\
\cline { 2 - 3 } & Night-time (unadjusted) & 0.6 \\
\hline Adequacy of training and & Adequate, high experience & -1.4 \\
\hline
\end{tabular}

Following the calculation of CII values for each main failure type, the CFP values are established to analyse gas turbine operational faults in conjunction with human factor. The equation (7) is implemented to calculate CFP. In Table 8 the adjusted CFP values are illustrated along with cognitive activity, cognitive function and generic failure type.

\subsection{Findings and Discussion}

Gas turbine systems consist of a very complex structure and are known to be a maintenance and repair operation for each equipment. As a consequence of this situation, problems can arise in the gas turbine components due to intense work, inexperience or technical insufficiency. For this reason, technical personnel have critical tasks.

In this study, human error probabilities in gas turbine faults were shaped by the answers given by the experts mentioned above and numerically expressed by the Cream method. The operational faults described in table 5 above and the hazards

Table 8. Adjusted CFP Values

\begin{tabular}{|l|l|l|l|l|l|}
\hline \multirow{2}{*}{ No } & Failure & $\begin{array}{l}\text { Cognitive } \\
\text { activity }\end{array}$ & $\begin{array}{l}\text { Cognitive } \\
\text { function }\end{array}$ & $\begin{array}{l}\text { Generic failure } \\
\text { type }\end{array}$ & Adjusted CFP \\
\hline \multirow{3}{*}{1} & F1. & Observe & Observation & O3 & $4,3 \mathrm{E}-02$ \\
\cline { 2 - 6 } & F2. & Execute & Execution & E3 & $3,1 \mathrm{E}-04$ \\
\cline { 2 - 6 } & F3. & Diagnose & Interpretation & I2 & $6,2 \mathrm{E}-03$ \\
\hline \multirow{3}{*}{2} & F4. & Co-ordinate & Planning & P2 & $5,6 \mathrm{E}-04$ \\
\cline { 2 - 6 } & F5. & Observe & Observation & 01 & $5,6 \mathrm{E}-05$ \\
\cline { 2 - 6 } & F6. & Plan & Planning & P2 & $5,6 \mathrm{E}-04$ \\
\hline \multirow{3}{*}{3} & F7. & Monitor & Observation & O3 & $8,9 \mathrm{E}-02$ \\
\cline { 2 - 6 } & F8. & Evaluate & Interpretation & I1 & $2,5 \mathrm{E}-01$ \\
\cline { 2 - 6 } & F9. & Co-ordinate & Planning & P2 & $1,3 \mathrm{E}-02$ \\
\hline \multirow{3}{*}{4} & F10. & Monitor & Observation & 03 & $8,9 \mathrm{E}-02$ \\
\cline { 2 - 6 } & F11. & Record & Execution & E2 & $3,8 \mathrm{E}-03$ \\
\cline { 2 - 6 } & F12. & Compare & Interpretation & I1 & $2,5 \mathrm{E}-01$ \\
\hline
\end{tabular}


that may occur due to these faults are expressed. The CFP values determined for the 14 critical faults for which human error probabilities are expressed for these operations are shown in Table 8. As a result of the answers of the experts, the CFP values range from 5,6E-05 to 2,5E-01. According to this result, Load control valve failure (F8; CFP Value: 2,5E-01), Fuel atomiser filter clogged (F12; CFP Value: 2,5E-01) calculated as the most effective criteria based on the human error. Valves and filters are known as the critical elements in terms of gas turbines. The filters have to be cleaned in time, and the maintenance of the valves must be done periodically. At this point, the importance of human impact is greater.

According to the results obtained in Table 8, Starter motor coupling failure (F2; CFP Value: 3,1E-04 and the oil pressure switch failure (F5; CFP Value: 5,6E-05) are defined as faults where the human effect is the fewest. This result is due to the fact that these faults are caused by mechanical problems rather than human influences.

These results, obtained through expert opinions and the CREAM method, represent the probability of human error in gas turbine faults. To minimize all these possibilities, the relevant personnel must follow operational procedures, take security precautions and control the flow of information.

\section{Conclusion}

Gas turbine systems are used in different areas of the industry. These systems have a low weight / power ratio compared to other engines. Because of this feature, it is also preferred in maritime. It is known that these systems consist of very complex components. In order to provide safe navigation in maritime, operational activities must be done meticulously in the ships where these systems are used. These operations are carried out on human control and minor negligence leads to major problems. In this study, 14 faults in the gas turbine components and the hazards that may occur due to this are stated. The human error probabilities that may cause these faults are calculated using the Cream method in the light of expert opinions. According to the results obtained, the technical personnel to be assigned by the shipowners must be more equipped and careful to prevent faults of high probability of human error. For further studies, the author aims to improve the methodology for assessing human errors on faults in gas turbine operations on board the ship.

\section{References}

[1] Islam, R., Khan, F., Abbassi, R., \& Garaniya, V. (2018). Human error probability assessment during maintenance activities of marine systems. Safety and health at work, 9(1), 42-52.

[2] De Felice, F., \& Petrillo, A. (2018). An Overview on Human Error Analysis and Reliability Assessment. In Human Factors and Reliability Engineering for Safety and Security in Critical Infrastructures (pp. 19-41). Springer, Cham.

[3] Sirignano, W. A., \& Liu, F. (1999). Performance increases for gas-turbine engines through combustion inside the turbine. Journal of propulsion and power, 15(1), 111-118.

[4] Doel, D. L. (1990, June). The role for expert systems in commercial gas turbine engine monitoring. In ASME 1990 International Gas Turbine and Aeroengine Congress and Exposition (pp. V005T15A014-V005T15A014). American Society of Mechanical Engineers.

[5] Bea, R. G. (1994). The Role of Human Error in Design, Construction, and Reliability of Marine Structures (No. SR1353). CALIFORNIA UNIV BERKELEY DEPT OF CIVIL ENGINEERING. 
[6] Dearden, A. M., \& Harrison, M. D. (1996, June). Impact and the design of the human-machine interface. In Computer Assurance, 1996. COMPASS'96, Systems Integrity. Software Safety. Process Security. Proceedings of the Eleventh Annual Conference on (pp. 161-170). IEEE.

[7] DePold, H. R., \& Gass, F. D. (1998, June). The application of expert systems and neural networks to gas turbine prognostics and diagnostics. In ASME 1998 International Gas Turbine and Aeroengine Congress and Exhibition (pp. V005T15A009-V005T15A009). American Society of Mechanical Engineers.

[8] Brotherton, T., Jahns, G., Jacobs, J., \& Wroblewski, D. (2000). Prognosis of faults in gas turbine engines. In Aerospace Conference Proceedings, 2000 IEEE (Vol. 6, pp. 163-171). IEEE.

[9] Latorella, K. A., \& Prabhu, P. V. (2000). A review of human error in aviation maintenance and inspection. International Journal of Industrial Ergonomics, 26(2), 133-161.

[10] Rothblum, A. M. (2000, October). Human error and marine safety. In National Safety Council Congress and Expo, Orlando, FL (p. 7).

[11] Ganguli, R. (2002). Fuzzy logic intelligent system for gas turbine module and system fault isolation. Journal of propulsion and power, 18(2), 440-447.

[12] Li, Y. G. (2002). Performance-analysisbased gas turbine diagnostics: A review. Proceedings of the Institution of Mechanical Engineers, Part A: Journal of Power and Energy, 216(5), 363-377.

[13] Mosleh, A., \& Chang, Y. H. (2004). Model-based human reliability analysis: prospects and requirements. Reliability Engineering \& System Safety, 83(2), 241-253.
[14] Konstandinidou, M., Nivolianitou, Z., Kiranoudis, C., \& Markatos, N. (2006). A fuzzy modeling application of CREAM methodology for human reliability analysis. Reliability Engineering \& System Safety, 91(6), 706-716.

[15] Dhillon, B. S., \& Liu, Y. (2006). Human error in maintenance: a review. Journal of quality in maintenance engineering, 12(1), 21-36.

[16] Kim, H. T., Na, S., \& Ha, W. H. (2011). A case study of marine accident investigation and analysis with focus on human error. Journal of the Ergonomics Society of Korea, 30(1), 137-150.

[17] Yang, Z. L., Bonsall, S., Wall, A., Wang, J., \& Usman, M. (2013). A modified CREAM to human reliability quantification in marine engineering. Ocean Engineering, 58, 293-303.

[18] Noroozi, A., Khan, F., MacKinnon, S., Amyotte, P., \& Deacon, T. (2014). Determination of human error probabilities in maintenance procedures of a pump. Process Safety and Environmental Protection, 92(2), 131-141.

[19] Islam, R., Abbassi, R., Garaniya, V., \& Khan, F. I. (2016). Determination of human error probabilities for the maintenance operations of marine engines. Journal of Ship Production and Design, 32(4), 226-234.

[20] Hollnagel, E., (1998). Cognitive reliability and error analysis method. Amsterdam: Elsevier.

[21] Akyuz, E. (2015). Quantification of human error probability towards the gas inerting process on-board crude oil tankers. Safety Science 80: 77-86

[22] Hollnagel, E., (1993). Human reliability analysis: Context and control. London, UK: Academic Press. 
[23] Akyuz, E. and Celik, M. (2015). Application of CREAM human reliability model to cargo loading process of LPG tankers. Journal of Loss Prevention in the Process Industries 34: 39 - 48.

[24] He, X., Wang, Y., Shen, Z., Huang, X., (2008). A simplified CREAM prospective quantification process and its application. Reliability Engineering and System Safety 93: 298-306.

[25] Apostolakis, G.E., Bier, V.M., Mosleh, A. (1988). A critique of recent models for human error rate assessment. Reliability Engineering and System Safety,22: 201 - 217.

[26] Balin, A., Demirel, H., \& Alarcin, F. (2016). A novel hybrid MCDM model based on fuzzy AHP and fuzzy TOPSIS for the most affected gas turbine component selection by the failures. Journal of Marine Engineering \& Technology, 15(2), 69-78.

[27] Balin, A., Demirel, H., \& Alarçin, F. (2016). An Evaluation Approach For Eliminating The Failure Effect In Gas Turbine Using Fuzzy Multiple Criteria. International Journal of Maritime Engineering, 158, A219-A230. 